\title{
The stable isotopic composition of molecular hydrogen in the tropopause region probed by the CARIBIC aircraft
}

\author{
A. M. Batenburg ${ }^{1}$, T. J. Schuck ${ }^{2}$, A. K. Baker ${ }^{2}$, A. Zahn ${ }^{3}$, C. A. M. Brenninkmeijer ${ }^{2}$, and T. Röckmann ${ }^{1}$ \\ ${ }^{1}$ Institute for Marine and Atmospheric research Utrecht, Utrecht University, Utrecht, The Netherlands \\ ${ }^{2}$ Max Planck Institute for Chemistry, Air Chemistry Division, Mainz, Germany \\ ${ }^{3}$ Karlsruhe Institute of Technology, Institute for Meteorology and Climate Research - Atmospheric Trace Gases and Remote \\ Sensing, Karlsruhe, Germany
}

Correspondence to: A. M. Batenburg (a.m.batenburg@uu.nl)

Received: 8 December 2011 - Published in Atmos. Chem. Phys. Discuss.: 9 January 2012

Revised: 2 May 2012 - Accepted: 4 May 2012 - Published: 24 May 2012

\begin{abstract}
More than 450 air samples that were collected in the upper troposphere - lower stratosphere (UTLS) region by the CARIBIC aircraft (Civil Aircraft for the Regular Investigation of the atmosphere Based on an Instrument Container) have been analyzed for molecular hydrogen $\left(\mathrm{H}_{2}\right)$ mixing ratios $\left(\chi\left(\mathrm{H}_{2}\right)\right)$ and $\mathrm{H}_{2}$ isotopic composition (deuterium content, $\delta \mathrm{D})$.

More than 120 of the analyzed samples contained air from the lowermost stratosphere (LMS). These show that $\chi\left(\mathrm{H}_{2}\right)$ does not vary appreciably with $\mathrm{O}_{3}$-derived height above the thermal tropopause (TP), whereas $\delta \mathrm{D}$ does increase with height. The isotope enrichment is caused by $\mathrm{H}_{2}$ production and destruction processes that enrich the stratospheric $\mathrm{H}_{2}$ reservoir in deuterium (D); the exact shapes of the profiles are mainly determined by mixing of stratospheric with tropospheric air. Tight negative correlations are found between $\delta \mathrm{D}$ and the mixing ratios of methane $\left(\chi\left(\mathrm{CH}_{4}\right)\right)$ and nitrous oxide $\left(\chi\left(\mathrm{N}_{2} \mathrm{O}\right)\right)$, as a result of the relatively long lifetimes of these three species. The correlations are described by $\delta \mathrm{D}[\% \mathrm{o}]=-0.35 \cdot \chi\left(\mathrm{CH}_{4}\right)[\mathrm{ppb}]+768$ and $\delta \mathrm{D}[\% \circ]=-1.90$. $\chi\left(\mathrm{N}_{2} \mathrm{O}\right)[\mathrm{ppb}]+745$. These correlations are similar to previously published results and likely hold globally for the LMS.

Samples that were collected from the Indian subcontinent up to $40^{\circ} \mathrm{N}$ before, during and after the summer monsoon season show no significant seasonal change in $\chi\left(\mathrm{H}_{2}\right)$, but $\delta \mathrm{D}$ is up to $12.3 \%$ o lower in the July, August and September monsoon samples. This $\delta \mathrm{D}$ decrease is correlated with the $\chi\left(\mathrm{CH}_{4}\right)$ increase in these samples. The significant correlation with $\chi\left(\mathrm{CH}_{4}\right)$ and the absence of a perceptible $\chi\left(\mathrm{H}_{2}\right)$ increase that accompanies the $\delta \mathrm{D}$ decrease indicates that mi-
\end{abstract}

crobial production of very D-depleted $\mathrm{H}_{2}$ in the wet season may contribute to this phenomenon.

Some of the samples have very high $\chi\left(\mathrm{H}_{2}\right)$ and very low $\delta \mathrm{D}$ values, which indicates a pollution effect. Aircraft engine exhaust plumes are a suspected cause, since the effect mostly occurs in samples collected close to airports, but no similar signals are found in other chemical tracers to support this. The isotopic source signature of the $\mathrm{H}_{2}$ pollution seems to be on the low end of the signature for fossil fuel burning.

\section{Introduction}

\subsection{Atmospheric Molecular Hydrogen $\left(\mathbf{H}_{2}\right)$}

Molecular hydrogen $\left(\mathrm{H}_{2}\right)$ has been a relatively little studied atmospheric trace gas for some time, but over the last decades, there has been a steep increase in research efforts into the global $\mathrm{H}_{2}$ cycle. These efforts have undoubtedly been spurred by the possible future use of $\mathrm{H}_{2}$ as an energy carrier. It is expected that when this technology comes into wide use, it will lead to leakage of $\mathrm{H}_{2}$ into the atmosphere, which may lead to considerably increased atmospheric $\mathrm{H}_{2}$ levels. This may affect the atmosphere's oxidative capacity and stratospheric ozone levels (Schultz et al., 2003; Warwick et al., 2004; Tromp et al., 2003; Feck et al., 2008). A number of global $\mathrm{H}_{2}$ budget estimates have been made (Novelli et al., 1999; Hauglustaine and Ehhalt, 2002; Sanderson et al., 2003; Rhee et al., 2006b; Price et al., 2007; Xiao et al., 2007; Ehhalt and Rohrer, 2009; Yashiro et al., 2011; Yver et al., 
2011; Bousquet et al., 2011; Pieterse et al., 2011, 2012). These estimates agree that the largest source of $\mathrm{H}_{2}$ to the atmosphere is oxidation of hydrocarbons, followed by combustion of fossil fuels and biomass (see Table 1). Production of $\mathrm{H}_{2}$ during $\mathrm{N}_{2}$-fixing by microbes on land or in the ocean constitutes a minor source. These source terms are balanced by two sink processes, uptake by soils (and subsequent destruction by enzymes) and atmospheric oxidation by the hydroxyl radical $(\mathrm{OH})$, of which soil uptake is the largest. Together, these processes result in typical atmospheric $\mathrm{H}_{2}$ mixing ratios $\left(\chi\left(\mathrm{H}_{2}\right)\right)$ of around $547 \mathrm{ppb}$ (nmole/mole) at ground level (Novelli et al., 1999, converted to the latest $\chi\left(\mathrm{H}_{2}\right)$ scale established by Jordan and Steinberg (2011)), with on average $3 \%$ higher values in the Southern Hemisphere. Model results indicate that $\chi\left(\mathrm{H}_{2}\right)$ may increase slightly with height, especially in the Northern Hemisphere extratropics (Hauglustaine and Ehhalt, 2002; Price et al., 2007; Pieterse et al., 2011). Despite the qualitative agreement, the uncertainties in the estimates of the magnitudes of the different terms in the budget are large.

\subsection{Stable isotope studies of $\mathrm{H}_{2}$}

Studies of the stable isotopic composition of $\mathrm{H}_{2}\left(\delta \mathrm{D}\left(\mathrm{H}_{2}\right)\right.$, or henceforth, $\delta \mathrm{D}$ ) can provide independent information to constrain the $\mathrm{H}_{2}$ budget. The isotope effects associated with sources and sinks of $\mathrm{H}_{2}$ (Table 1) are particularly large due to the large relative mass difference between deuterated hydrogen (HD) and "ordinary" hydrogen $(\mathrm{HH})$. We define $\delta \mathrm{D}$ as:

$\delta \mathrm{D}=\delta \mathrm{D}\left(\mathrm{H}_{2}\right)=\left(\frac{R_{\text {Sample }}}{R_{\mathrm{VSMOW}}}-1\right) \cdot 1000 \%$

where $R_{\text {Sample }}$ is the ratio of the number of deuterium atoms (D) to protium atoms ("ordinary" hydrogen atoms, $\mathrm{H}$ ) in the sample $\mathrm{H}_{2}$, and $R_{\text {VSMOW }}$ is this D/H ratio in Vienna Standard Mean Ocean Water. Recently, isotope effects in the production processes of $\mathrm{H}_{2}$ have been studied (Gerst and Quay, 2001; Rahn et al., 2002b, 2003; Röckmann et al., 2003; Rhee et al., 2006a; Feilberg et al., 2007; Rhee et al., 2008; Röckmann et al., 2010a,b; Vollmer et al., 2010; Walter et al., 2011; Haumann et al., 2012), as well as the isotope effects in the $\mathrm{H}_{2}$ uptake by soils (Gerst and Quay, 2001; Rahn et al., 2002a; Rice et al., 2011).

Two chemical transport models have been adapted to incorporate the stable isotopic composition of $\mathrm{H}_{2}$, namely GEOS-CHEM (Price et al., 2007) and TM5 (Pieterse et al., $2009,2011,2012)$, and many more $\delta \mathrm{D}$ data have become available for the validation of such models (Rice et al., 2010; Batenburg et al., 2011). However, for obvious practical reasons, most of these data were collected at ground level, and yield little information about processes higher up in the atmosphere, particularly in the Upper TroposphereLower Stratosphere (UTLS) region. This is problematic since Stratosphere-Troposphere Exchange (STE) in the UTLS may
Table 1. The global $\mathrm{H}_{2}$ budget and isotope budget as estimated by Pieterse et al. (2011) in a model study with global model TM5. The estimated magnitudes, isotopic signatures and uncertainties (superand subscript numbers) of the different surface sources were based on previous studies. For biomass burning, the estimated source signature was based on measurements that were later published in Röckmann et al. (2010a). The magnitudes and isotope effects of the photochemical processes and the soil uptake were calculated from the model output; in this first $\mathrm{H}_{2}$ study with TM5, no estimates of the uncertainties associated with these terms were made yet. At the bottom of the table are estimates by different authors of the global average $\chi\left(\mathrm{H}_{2}\right)$ and $\delta \mathrm{D}\left(\mathrm{H}_{2}\right)$.

\begin{tabular}{|c|c|c|}
\hline Sources & $\begin{array}{l}\text { Magnitude } \\
\left(\mathrm{Tg} \mathrm{H}_{2} \mathrm{yr}^{-1}\right)\end{array}$ & $\delta \mathrm{D}(\% \circ)$ \\
\hline Fossil fuel combustion & $17.0_{-6}^{+3}$ & $-196_{-74}^{+10 a}$ \\
\hline Biomass burning & $15.0_{-5}^{+6}$ & $\begin{array}{r}-74 \\
-260_{-60}^{+60}\end{array}$ \\
\hline Ocean $\mathrm{N}_{2}$ fixation & $5.0_{-2}^{+\overline{1}^{3}}$ & $-628_{-72}^{+60}$ \\
\hline Land $\mathrm{N}_{2}$ fixation & $3.0_{-3}^{+3}$ & $-628_{-72}^{+0 b}$ \\
\hline Photochemical production & 37.3 & +116 \\
\hline Total sources & 77.3 & \\
\hline Sinks & $\begin{array}{l}\text { Magnitude } \\
\left(\mathrm{Tg} \mathrm{H}_{2} \mathrm{yr}^{-1}\right)\end{array}$ & $\begin{array}{l}\text { Fractionation } \\
\text { coefficient } \\
\left(\alpha=\frac{k_{\mathrm{HD}}}{k_{\mathrm{HH}}}\right)\end{array}$ \\
\hline $\begin{array}{l}\text { Photochemical removal } \\
\text { (mainly by } \mathrm{OH} \text { ) }\end{array}$ & 22.1 & 0.542 \\
\hline Deposition to soils & 55.8 & 0.925 \\
\hline Total sinks & 77.9 & \\
\hline \multirow[t]{2}{*}{ Global averages } & $\chi\left(\mathbf{H}_{2}\right)$ & $\delta \mathbf{D}\left(\mathbf{H}_{2}\right)$ \\
\hline & $547 \mathrm{ppb}^{\mathrm{c}}$ & +124 to $+150 \% o^{d}$ \\
\hline
\end{tabular}

a Results from Vollmer et al. (2010) indicate that this source signature may be lower for modern cars and certain driving conditions. Results from a polluted station in the Netherlands also indicate this (Batenburg et al., 2012). ${ }^{\mathrm{b}}$ Walter et al. (2011) found this source signature to be $(-741 \pm 13) \%$ o. ${ }^{c}$ Novelli et al. (1999) ${ }^{d}$ Depending on latitude, Batenburg et al. (2011)

be one of the main processes that enrich the global tropospheric $\mathrm{H}_{2}$ reservoir. Both Price et al. (2007) and Pieterse et al. (2011) estimated that STE contributes several tens of \%o to the global tropospheric $\delta \mathrm{D}$ average. Furthermore, Pieterse et al. (2011) found that the magnitude of the contribution was highly sensitive to the $\delta \mathrm{D}$ value assumed for the stratosphere. A good parameterization of the isotope effects of STE is therefore necessary to reduce the uncertainties in the modeled isotope budget, which is, in turn, necessary to be able to use the isotopes to constrain the global $\mathrm{H}_{2}$ budget. A number of investigations have been conducted in the stratosphere (Rahn et al., 2003; Röckmann et al., 2003; Rhee et al., 2006a), but only three of the samples analyzed for these studies were sampled below $14 \mathrm{~km}$ altitude. Rhee et al. (2006b) presented data from three previous CARIBIC (Civil Aircraft for the Regular Investigation of the atmosphere Based on an Instrument Container) flights, but focused only on the 
tropospheric samples, and actually omitted those samples near the tropopause (TP) or in the lowermost stratosphere (LMS) from further analysis.

Not only are some altitudes underrepresented in the published $\delta \mathrm{D}$ data, also some regions of the world are not well covered. Previously published data were mostly from samples collected at two stations at the west coast of North America and on Pacific Ocean transects (Gerst and Quay, 2000; Rice et al., 2010), or at stations in Europe and the polar regions (Batenburg et al., 2011). Data from other regions, such as South Asia, are scarce.The aim of analyzing data from the CARIBIC program is to close both the altitudinal and the regional gap in the observations.

The CARIBIC project uses a passenger aircraft to make in-situ measurements and to sample air and aerosol at aircraft cruise altitude, generally between 9 and $11 \mathrm{~km}$. At this altitude, the aircraft intercepts both upper troposphere and lowermost stratosphere air masses in similar quantities at midlatitudes. CARIBIC is therefore a very suitable platform to study the UTLS region. The obtained information is somewhat Eurocentric, because the aircraft is based at Frankfurt airport (Fig. 1). Nevertheless, a large region of the globe is covered, including the Indian subcontinent where air was sampled before, during and after the summer monsoon season. To our knowledge, this paper presents the first $\delta \mathrm{D}$ observations that have been made in or over India. The results of measurements of greenhouse gases (GHGs) in the South Asian samples discussed here have been published previously by Schuck et al. (2010). These revealed an increase in greenhouse gas mixing ratios during the monsoon season, especially for methane $\left(\mathrm{CH}_{4}\right)$. This was attributed to increased $\mathrm{CH}_{4}$ emissions from rice paddies and wetlands, and increased convective transport that brought the $\mathrm{CH}_{4}$ to aircraft cruising altitude. The $\delta \mathrm{D}$ data from these samples provide a unique opportunity to study possible $\delta \mathrm{D}$ effects in the convective monsoon system.

\section{$1.3 \delta \mathrm{D}$ in the stratosphere}

$\mathrm{H}_{2}$ mixing ratios vary little in the stratosphere, but isotope information reveals that $\mathrm{H}_{2}$ is involved in stratospheric reactions. Deuterium enrichments of more than $250 \%$ above typical tropospheric values $(\approx+130 \%$ ) were found during a stratospheric research aircraft campaign (Rahn et al., 2003) and stratospheric balloon campaigns (Röckmann et al., 2003; Rhee et al., 2006a). These are evidence that production and destruction of $\mathrm{H}_{2}$ do take place; that $\chi\left(\mathrm{H}_{2}\right)$ remains unchanged means that $\mathrm{H}_{2}$ production (by methane oxidation) and destruction (by its own oxidation) are of almost equal magnitude. Since $\delta \mathrm{D}$ varies much more in the stratosphere than $\chi\left(\mathrm{H}_{2}\right)$, it contains much more information about the stratospheric cycles of $\mathrm{H}_{2}$ and other $\mathrm{H}$-containing compounds $\left(\mathrm{CH}_{4}, \mathrm{HCHO}, \mathrm{H}_{2} \mathrm{O}, \ldots\right)$ than $\chi\left(\mathrm{H}_{2}\right)$.

Plumb (2007) found that compact correlations between stratospheric species are common, as the time scales for

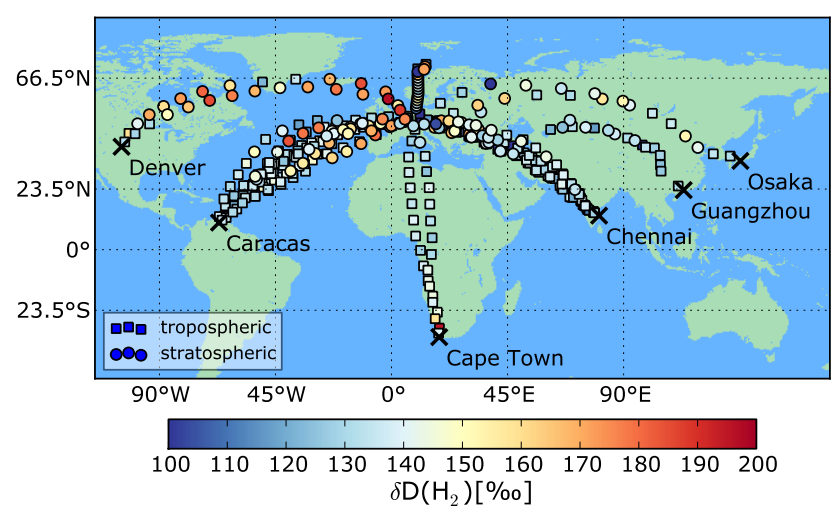

Fig. 1. Sampling locations of all samples. The color scale indicates the measured value of $\delta \mathrm{D}$. The destination airports of the flights are indicated with black crosses and names. Marker type indicates if the sample is tropospheric ( $\square$ ) or stratospheric (o), as determined by the $\mathrm{O}_{3}$-derived height above the tropopause (TP) (Sprung and Zahn, 2010). Some polluted samples are off the scale $(\delta \mathrm{D}<100 \%$ o $)$

stratospheric transport are shorter than the chemical lifetimes of (relatively) long-lived trace gases. Due to this, all the data from Rahn et al. (2003), Röckmann et al. (2003) and Rhee et al. (2006a) show a compact inverse correlation between $\delta \mathrm{D}$ and methane $\left(\mathrm{CH}_{4}\right)$ mixing ratios $\left(\chi\left(\mathrm{CH}_{4}\right)\right)$. So, as the air ages, $\mathrm{CH}_{4}$ is destroyed, and $\mathrm{H}_{2}$ is both produced and destroyed by processes that cause a net $\mathrm{D}$-enrichment.

$\mathrm{H}_{2}$ removal by $\mathrm{OH}$ has a strong preference for removal of HH over removal of HD (Talukdar et al.,1996, see also Table 1) and therefore enriches the remaining $\mathrm{H}_{2}$ reservoir. However, to explain the total observed enrichments, also the $\mathrm{H}_{2}$ produced from $\mathrm{CH}_{4}$ must be D-enriched. The first step in the chain of reactions that leads from $\mathrm{CH}_{4}$ to $\mathrm{H}_{2}$ is the abstraction of an $\mathrm{H}$ atom from $\mathrm{CH}_{4}$, and the last step is photolysis of the intermediate product formaldehyde (HCHO). Both these steps proceed more slowly for the deuterated than for the non-deuterated species (Sander et al., 2006; Feilberg et al., 2007; Rhee et al., 2008; Röckmann et al., 2010b), but these effects are offset by D-enriching effects in the other reactions in the chain (Nilsson et al., 2007). For the total process, stratospheric $(\delta \mathrm{D})$ source signatures between +130 and $+370 \%$ were reported (Rahn et al., 2003; Röckmann et al., 2003; Rhee et al., 2006a). Results from the TM5 model indicate that the source signature is likely in the low end of this range (Pieterse et al., 2011, see also Table 1). Also, a lab study by Nilsson et al. (2010) showed that the isotope effects are pressure dependent.

McCarthy et al. (2004) presented parametrizations of $\delta \mathrm{D}$ and the mixing ratio of deuterated hydrogen $(\chi(\mathrm{HD}))$ relative to $\chi\left(\mathrm{CH}_{4}\right)$, based on the data from Rahn et al. (2003). Pieterse et al. $(2011,2012)$ used this to obtain the first results with the TM5 model, but had to apply a large correction to keep the model results close to observed tropospheric $\delta \mathrm{D}$ values. The CARIBIC data presented here allow us to calculate 
a new correlation between $\delta \mathrm{D}$ and $\chi\left(\mathrm{CH}_{4}\right)$. As such a correlation is based on samples collected close to the TP, we would consider it a very suitable choice for parameterizing $\delta \mathrm{D}$ from $\chi\left(\mathrm{CH}_{4}\right)$ in the LMS in models.

\section{Experimental}

\subsection{Sampling and in-situ measurements}

The CARIBIC Airbus A340-600 is equipped with a $35 \mathrm{~cm}$ tall inlet system with several intake probes, which is located underneath just in front of the belly fairing (Brenninkmeijer et al., 2007). Air from the trace gas inlet probe passes through heated PFA-lined stainless steel tubing $\left(\approx 40^{\circ} \mathrm{C}\right)$ to the equipment in the automated CARIBIC measurement container. Here, whole air samples are collected by the socalled TRAC (Triggered Retrospective Air Collector) (Brenninkmeijer et al., 2007; Schuck et al., 2009). This system consists of a pumping unit and two separate sample units, controlled by a computer unit. Each sample unit contains 14 glass cylinders with a volume of 2.671 each that during sampling are pressurized to an effective pressure of 3.5 to 4.2 bar. During flight, sampling starts after a pressure cutoff level ( $450 \mathrm{mbar}$ ) is reached to avoid sampling of low-level polluted air in the vicinity of airports. By flushing, the air within each flask is replaced approximately ten times before the actual sample is taken. The pressurization of the sample to the final pressure then takes from 0.5 to $1.5 \mathrm{~min}$, which corresponds to a flight distance of 7 to $21 \mathrm{~km}$ (this varies as it takes longer to fill the samples to the required minimum final pressure at higher altitude). A flask is filled every hour or half hour at points evenly distributed over the expected flight time. On arrival back in Frankfurt, one of the sample units usually contains samples from the first flight leg (Frankfurt to destination) and the other contains samples from the return flight (destination to Frankfurt). With this method of regular, automated, non-event-driven sampling, the distribution of samples is likely representative of the different air masses encountered by the aircraft. Schuck et al. (2009) showed that this was the case for carbon dioxide mixing ratios $\left(\chi\left(\mathrm{CO}_{2}\right)\right)$ in these samples.

Ozone $\left(\mathrm{O}_{3}\right)$ mixing ratios $\left(\chi\left(\mathrm{O}_{3}\right)\right)$ and carbon monoxide (CO) mixing ratios $(\chi(\mathrm{CO}))$ are measured in-flight. $\chi\left(\mathrm{O}_{3}\right)$ is measured with a custom made UV-photometer (Brenninkmeijer et al., 2007), and $\chi(\mathrm{CO})$ is measured with a vacuum ultraviolet fluorescence instrument (Scharffe et al., 2012). These measurements are integrated over the TRAC sampling times to obtain the $\chi\left(\mathrm{O}_{3}\right)$ and $\chi(\mathrm{CO})$ value for each TRAC sample. The ozone values are then used to estimate the height above the thermal TP with the method of Sprung and Zahn (2010).

Meteorological plots and trajectory calculations are routinely produced for each CARIBIC flight by the KNMI (van Velthoven, 2009), based on European Centre for Medium
Range Weather Forecasts (ECMWF) data. For the calculation of the mean trajectory parameters for each sample, 15 five-day trajectories are generated that start at the same time, but at slightly different locations or pressures. These are combined into one mean trajectory by averaging at each one-hour timestep; the parameters are then calculated from the mean trajectory.

\subsection{GHG analysis}

The samples that are collected in the TRAC units are routinely analyzed for $\mathrm{CH}_{4}, \mathrm{CO}_{2}$, nitrous oxide $\left(\mathrm{N}_{2} \mathrm{O}\right)$ and sulfur hexafluoride $\left(\mathrm{SF}_{6}\right)$ mixing ratios $\left(\chi\left(\mathrm{CH}_{4}\right), \chi\left(\mathrm{CO}_{2}\right), \chi\left(\mathrm{N}_{2} \mathrm{O}\right)\right.$ and $\left.\chi\left(\mathrm{SF}_{6}\right)\right)$ at the Max Planck Institute for Chemistry in Mainz on a gas chromatography system. This uses an HP 6890 gas chromatograph with two simultaneously operated channels: one to measure $\chi\left(\mathrm{CO}_{2}\right)$ and $\chi\left(\mathrm{CH}_{4}\right)$ with a Flame Ionization Detector (FID) and one to measure $\chi\left(\mathrm{N}_{2} \mathrm{O}\right)$ and $\chi\left(\mathrm{SF}_{6}\right)$ with an Electron Capture Detector (ECD). Four injections are made for each sample, and the repeatability for each datapoint is determined from the standard deviation of the four injections. The measurement of each sample is bracketed by the measurement of a laboratory working gas to detect any instrument drift. These laboratory working gases are calibrated against NOAA standards. $\chi\left(\mathrm{CH}_{4}\right)$ values reported in this paper are on the NOAA 2004 scale, and $\chi\left(\mathrm{N}_{2} \mathrm{O}\right)$ values are on the NOAA 2006 scale.

\subsection{Analysis of $\chi\left(\mathrm{H}_{2}\right)$ and $\delta \mathrm{D}$}

A subset of the samples collected by the TRAC, 490 in total, was sent to the isotope laboratory of the Intitute for Marine and Atmospheric Research Utrecht (IMAU). Here, air samples are routinely analyzed for $\chi\left(\mathrm{H}_{2}\right)$ and $\delta \mathrm{D}$ with a Gas Chromatography Isotope Ratio Mass Spectrometry (GCIRMS) system as described by Rhee et al. (2004) following a day-to-day procedure as described by Batenburg et al. (2011). Briefly, in each acquisition the $\mathrm{H}_{2}$ is separated from the air matrix and isotopically analyzed in the following 4 steps.

1. Trapping of all air components except helium, hydrogen, neon and a trace of nitrogen in an $\approx 0.5 \mathrm{~L}$ (STP) aliquot of sample air by exposure to $\mathrm{a} \approx 40 \mathrm{~K}$ cold head.

2. Pre-concentration of the $\mathrm{H}_{2}$ from the head space of the cold head by flushing it with helium through a trap filled with $5 \AA$ molecular sieve kept at $\approx 63 \mathrm{~K}$ by submersion in liquid nitrogen at reduced pressure.

3. Focussing of the $\mathrm{H}_{2}$ pulse in a cryo-focus trap consisting of a steel-jacketed $5 \AA$ molecular sieve capillary submersed in liquid nitrogen $(77 \mathrm{~K})$ and final purification on a $5 \AA$ molecular sieve gas chromatography column kept at $323 \mathrm{~K}$. 
4. Injection of the purified $\mathrm{H}_{2}$ through an open split interface into an IRMS (ThermoFinnigan Delta plus XL) for determination of the $\mathrm{D} / \mathrm{H}$ ratio.

469 samples were successfully analyzed for $\chi\left(\mathrm{H}_{2}\right)$ and $\delta \mathrm{D}$. Ten of these samples were collected below $6 \mathrm{~km}$ altitude during a special flight to investigate the plume of the $2010 \mathrm{Ey}-$ jafjallajökull eruption and are left out of further analysis.

Measurements of air from laboratory reference air bottles, as well as blank measurements, were typically performed every operational day following the same procedure as for the samples. The 5-day moving average values of these reference measurements were used to calculate the corrected $\chi\left(\mathrm{H}_{2}\right)$ and $\delta \mathrm{D}$ for each sample. From measurements of other samples on this system it was concluded that measurements performed from June 2010 onwards had a positive bias in $\delta$ D (Batenburg et al., 2011). An empirically determined offset of $9.5 \%$ was therefore subtracted from all CARIBIC $\delta \mathrm{D}$ datapoints measured after this time. To the $\chi\left(\mathrm{H}_{2}\right)$ data a linear empirical correction formula was applied that was derived from a comparison of the GC-IRMS results with results from collaborating laboratories within the EUROHYDROS project. The estimated standard deviation $(\sigma)$ in the measurements of $\chi\left(\mathrm{H}_{2}\right)$ is $2.5 \%$ (relative), and the estimated standard deviation in $\delta \mathrm{D}$ is $4.5 \%$ (absolute).

\subsection{Selection of stratospheric and polluted samples}

Sprung and Zahn (2010) presented a method to translate the observed $\chi\left(\mathrm{O}_{3}\right)$ for a sample to an estimate of the vertical distance above the thermal TP by interpolation from vertical $\chi\left(\mathrm{O}_{3}\right)$ profiles observed during balloon soundings at 12 ground stations (Sprung and Zahn, 2010). This estimate can be made for any sample with a $\chi\left(\mathrm{O}_{3}\right)$ higher than at the local thermal TP. All 123 TRAC samples for which this estimate could be made are considered 'stratospheric', the 336 others are considered "tropospheric". This selection criterion was chosen to accurately resolve the chemical fine structure of the TP.

For some samples, often taken close to take-off and landing of the aircraft, the GC-IRMS analysis yielded very high $\chi\left(\mathrm{H}_{2}\right)$ and very low $\delta \mathrm{D}$ values, indicating that these samples were affected by pollution. Samples were flagged as polluted by an iterative process that was applied separately to the tropospheric and stratospheric samples, as follows: samples that were more than three standard deviations below the (unweighted) average value of $\delta \mathrm{D}$ or three standard deviations above the (unweighted) average $\chi\left(\mathrm{H}_{2}\right)$ were filtered out of a list of the data, after which new averages and standard deviations were calculated. This was repeated until no new outlying samples were found, and the resulting averages were used to label each sample that showed a $\delta \mathrm{D}$ value more than three standard deviations below the new $\delta \mathrm{D}$ average, or an $\chi\left(\mathrm{H}_{2}\right)$ value more than three standard deviations above the new $\chi\left(\mathrm{H}_{2}\right)$ average as polluted. Three (out of 123) strato-

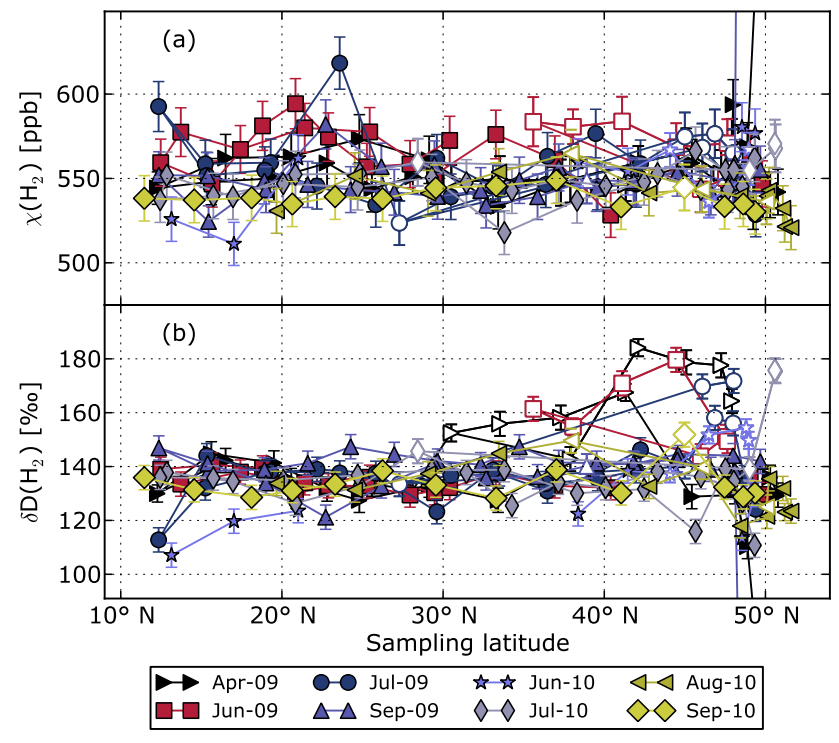

Fig. 2. Latitudinal distribution of $\chi\left(\mathrm{H}_{2}\right)$ (a) and $\delta \mathrm{D}$ (b) data from samples that were collected on flights to Caracas, Venezuela. Stratospheric samples are indicated with open symbols. Two (polluted) samples are off the scales.

spheric and 25 (out of 336) tropospheric samples were labelled as polluted by this process.

\section{Results and discussion}

The geographical distribution of the analyzed samples is shown in Fig. 1. The color scale indicates the measured $\delta \mathrm{D}$, and the type of marker indicates whether the sample is tropospheric or stratospheric. It can be seen that due to the use of one base airport, the area that is covered is not global, although it is large. Only one of the analyzed stratospheric samples was collected in the Southern Hemisphere, and no samples were collected over the Pacific Ocean. Europe and the North Atlantic are the best covered regions, and also the Middle East and Central Asia are reasonably well covered. Except the samples that were collected below $6 \mathrm{~km}$ altitude and left out of the analysis, all samples were collected between 6.9 and $12.3 \mathrm{~km}$ altitude, with an average altitude of $10.9(\sigma=0.8) \mathrm{km}$. The months in which the largest number of analyzed samples were collected are May, July and September, whereas none of the samples were collected in December, January and February.

As an illustration of the features that are typically observed in the CARIBIC dataset, Fig. 2 shows the $\chi\left(\mathrm{H}_{2}\right)$ and $\delta \mathrm{D}$ values that were measured on those samples that were collected on flights to Caracas (Venezuela). The flights from April 2009 and September 2009 show the pollution phenomenon discussed above; in both return flights, one sample that is taken close to Frankfurt airport $\left(50.1^{\circ} \mathrm{N}\right)$ shows very high $\chi\left(\mathrm{H}_{2}\right)$ and very low $\delta \mathrm{D}$ values (off the scales). 
Another feature that is illustrated by these plots is that the stratospheric samples (shown with open symbols) often show a marked elevation in $\delta \mathrm{D}$ with respect to the tropospheric samples as a result of stratospheric processing, whereas no difference in $\chi\left(\mathrm{H}_{2}\right)$ can be noted by eye.

Averaged over the whole unpolluted dataset, the tropospheric $\chi\left(\mathrm{H}_{2}\right)$ and $\delta \mathrm{D}$ averages and standard errors (SEM) are $(550.5 \pm 0.9) \mathrm{ppb}(311$ samples, $\sigma=16.6 \mathrm{ppb})$ and $(132.8 \pm 0.4) \% o(\sigma=7.1 \%)$, respectively. For the stratosphere, these values are $(559.8 \pm 1.5) \mathrm{ppb}(120$ samples, $\sigma=16.1 \mathrm{ppb})$ and $(151.8 \pm 1.6) \% o(\sigma=17.4 \% o)$. The difference between troposphere and stratosphere is larger for $\delta \mathrm{D}$, but for both $\chi\left(\mathrm{H}_{2}\right)$ and $\delta \mathrm{D}$, the difference is significant with $95 \%$ confidence.

\subsection{Pollution signatures}

In the total dataset of 459 successful measurements, 28 samples were labeled as polluted by the iterative selection procedure. Nine of these samples were in the first canister (number 1 or 15) of a TRAC sample unit, and eight were in the last (number 14 or 28). These two endcanisters are filled closest to the departure or destination airport (of the total of 14 canisters in a TRAC sample unit). Clearly, this pollution effect has a very strong tendency to occur there. Typically, the first sample in the sample unit is collected at the lowest altitude, as the aircraft usually follows a slightly upward sloping flight route. Therefore, pollution from the boundary layer was a suspected cause. However, a study of the calculated backward trajectories of these samples showed that only a minority of the outlying samples (eight, of which five in the first TRAC sample unit canister) had possible boundary layer influence.

Because of this, and because of the strong tendency to occur in the vicinity of airports where a large concentration of airplanes are present, we consider the interception of exhaust plumes of other aircraft in the flight corridor a possible cause. As exhaust plumes are occasionally seen by equipment in the container as sharp spikes in $\mathrm{NO}_{\mathrm{x}}$ and $\mathrm{NO}_{\mathrm{y}}$ (Ziereis et al., 2000), we inspected all data to see if the finding of polluted $\mathrm{H}_{2}$ values coincided with $\mathrm{NO}_{\mathrm{x}}$ and $\mathrm{NO}_{\mathrm{y}}$ spikes. Unfortunately, the $\mathrm{NO}_{\mathrm{x}} / \mathrm{NO}_{\mathrm{y}}$ measurements often began (just) after the first canister was filled, and ended before the last, so for the polluted samples in the first and last canisters of the TRAC sampling unit this information was often not available. For the polluted samples for which $\mathrm{NO}_{\mathrm{x}} / \mathrm{NO}_{\mathrm{y}}$ measurements were available, a clear relation between polluted samples and $\mathrm{NO}_{\mathrm{x}} / \mathrm{NO}_{\mathrm{y}}$ spikes was not found. Aerosol data were more often available (Brenninkmeijer et al., 2007), but no clear relation was found with either N4-12, N12 or N18 particle numbers (numbers indicate particle size in $\mathrm{nm}$ ). Because of this lack of correlation with other species, the origin of these pollution signatures cannot be definitively established.

An artifact in the measurement system is unlikely, because the measurements of these samples proceeded without peculiarities. The TRAC samples are kept in glass flasks con-

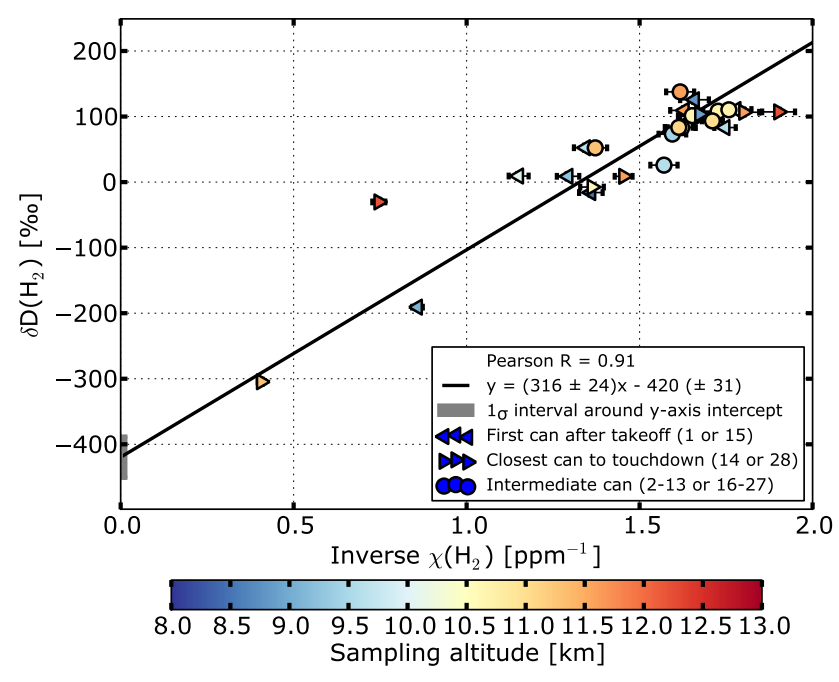

Fig. 3. Keeling plot ( $\delta \mathrm{D}$ vs. inverse $\chi\left(\mathrm{H}_{2}\right)$ ) for those samples that were labeled as polluted with the iterative selection procedure. The solid line is a linear fit through all the data with the "WilliamsonYork" (W-Y) algorithm that takes the variance and the estimated errors in both the $\mathrm{x}$ - and $\mathrm{y}$-direction into account (Cantrell, 2008). The $1 \times$ SEM (standard error) interval around the axis intercept of the fit is indicated in grey on the vertical axis. The marker type indicates in which part of a flight the sample was taken; the marker color indicates sampling altitude.

nected to Valco multiposition valves with stainless steel tubing. Gerst and Quay (2000) found that D-depleted $\mathrm{H}_{2}$ can form in metal cylinders, possibly associated with water vapor in the sample. However, the surface area of stainless steel in the TRAC tubing and valves is very small. So although the formation of $\mathrm{H}_{2}$ from water vapor on the metal parts could explain why the phenomenon so often occurs at the beginning and the end of flights, where the water vapor levels are (much) higher than during the rest of the flight (as the flight altitude is lower), it is not a likely process. Moreover, the occurrences of such pollution effects in intermediate canisters were not associated with water vapor peaks.

To determine the isotopic signature of the pollution source, a so-called Keeling plot was made ( $\delta \mathrm{D}$ plotted against inverse $\chi\left(\mathrm{H}_{2}\right)$ ) of the datapoints that met the pollution criterion (Fig. 3). One sample that was taken close to Cape Town and had both an elevated $\chi\left(\mathrm{H}_{2}\right)$ and an elevated $\delta \mathrm{D}$ value was left out of this plot. The marker type indicates to which category of can (closest to takeoff, closest to touchdown or intermediate) the sample belongs, and the marker color indicates sampling altitude. It can be observed that the samples that have the clearest pollution signatures were in the endcanisters. We also note that the samples closest to takeoff are usually collected at lower altitudes (color scale), but that there is no clear relation between sampling altitude and the degree of pollution.

The linear fit to this Keeling plot was made using the Williamson-York (W-Y) algorithm described by Cantrell 

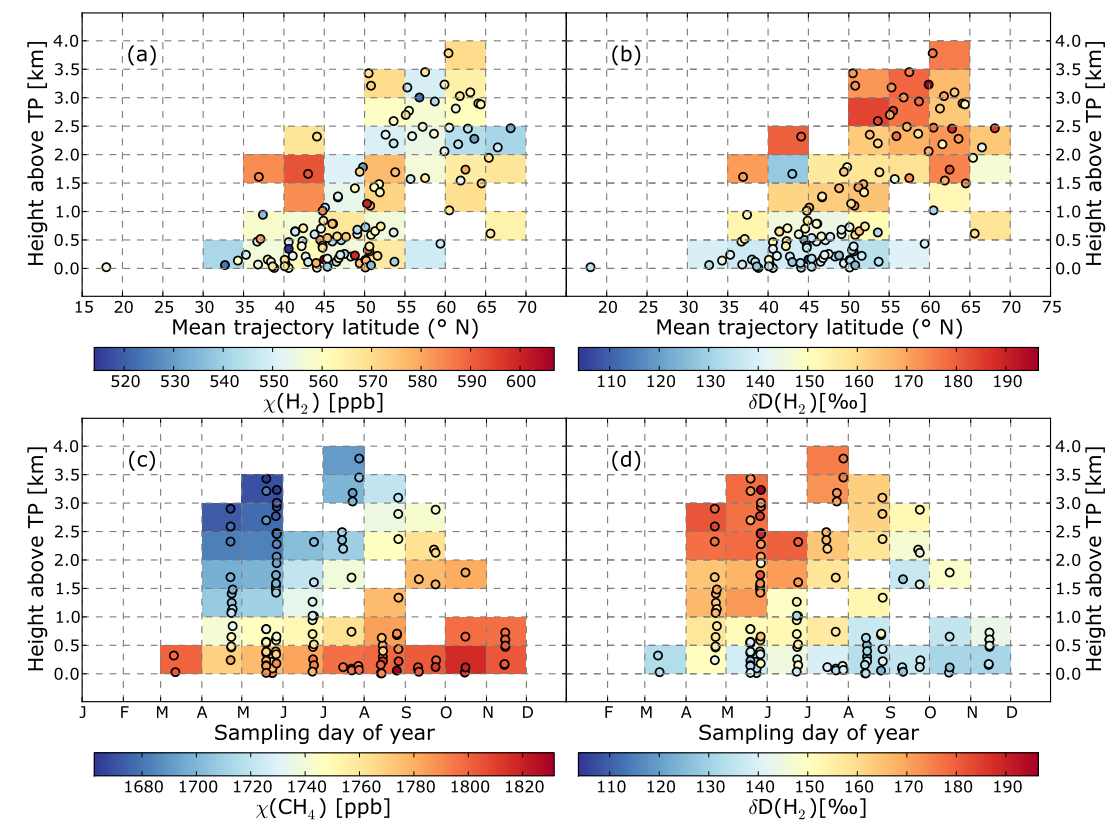

Fig. 4. Distributions of $\chi\left(\mathrm{H}_{2}\right)$ (a), $\delta \mathrm{D}\left(\mathrm{H}_{2}\right)(\mathbf{b}), \chi\left(\mathrm{CH}_{4}\right)$ (c) and $\delta \mathrm{D}\left(\mathrm{H}_{2}\right)$ (d) in the stratospheric samples plotted against height above the thermal TP (calculated from the $\mathrm{O}_{3}$ measurements following the method of Sprung and Zahn (2010)) and mean trajectory latitude (calculated from the 15 five-day trajectories) $(\mathbf{a}, \mathbf{b})$ or time of year $(\mathbf{c}, \mathbf{d})$. The rectangles are colored according to the averages of the samples in the rectangles.

(2008). In contrast to a simple least-squares fit, this algorithm takes the variance and the estimated uncertainties in both the $\mathrm{x}$ - and the $\mathrm{y}$-values of the data into account. This fit yields a very depleted source signature $((-420 \pm 31) \%$, y-axis intercept) for the $\mathrm{H}_{2}$ produced by the pollution source. This is very low compared to the commonly accepted values for fossil fuel or biomass burning emissions (see Table 1). Omission of the three most polluted data points in the fit increased the source signature to $(-364 \pm 60) \%$, which is still quite low. No data on the isotopic composition of $\mathrm{H}_{2}$ produced by combustion of kerosine in jet engines are available, and whether the deuterium signature of $\mathrm{H}_{2}$ produced by jet engines may be lower than that of $\mathrm{H}_{2}$ from other fossil fuel combustion sources is unknown.

\subsection{The stratosphere}

The sampling location of each of the 123 selected stratospheric samples is indicated in Fig. 1 by circles, with the color representing $\delta \mathrm{D}$ according to the color scale. Most of the stratospheric samples that are at the high end of this scale were taken on a flight to Denver (USA) in May 2009. The aircraft reached high latitudes $\left(>70^{\circ} \mathrm{N}\right)$ en route to this destination. Samples collected at higher latitudes have on average higher $\delta \mathrm{D}$ values, firstly because the TP slopes down with latitude and the aircraft therefore penetrates more deeply into the stratosphere at higher latitudes, and secondly because the average degree of stratospheric processing of the air masses is higher at higher latitudes due to the general poleward pattern of stratospheric circulation (Holton et al., 1995).

The average degree of stratospheric processing of air generally increases with distance above the TP, and therefore stratospheric $\delta \mathrm{D}$ values also increase with altitude. For all stratospheric samples, an $\mathrm{O}_{3}$-derived estimate of the height above the TP was available (in fact, this is how these samples were selected, see Sect. 2.4). The $\mathrm{O}_{3}$-derived altitude is not the same as the instantaneous altitude above the TP. Instead, it can be considered as a measure of the degree of mixing between low- $\mathrm{O}_{3}$ air from the troposphere and high$\mathrm{O}_{3}$ air from the stratosphere. As detailed by Sprung and Zahn (2010), it is a robust method to quantify a "chemical" vertical coordinate around the tropopause. When $\chi\left(\mathrm{H}_{2}\right)$ and $\delta \mathrm{D}$ are plotted against mean trajectory latitude and this $\mathrm{O}_{3}$-derived height above the TP (Fig. 4a and b) it is clearly visible that $\delta \mathrm{D}$ increases with distance to the TP, whereas $\chi\left(\mathrm{H}_{2}\right)$ does not. These figures also show that with the CARIBIC sampling method, the samples collected at the largest distance above the TP are generally collected at the highest latitudes. Figure $4 \mathrm{c}$ shows the seasonal variation in the $\chi\left(\mathrm{CH}_{4}\right)$ profile in the measured samples. In Northern Hemisphere (NH) spring subsidence occurs of air masses with low $\chi\left(\mathrm{CH}_{4}\right)$. This pattern is almost exactly inversely mirrored in the seasonal variation in the $\delta \mathrm{D}$ profiles in Fig. $4 \mathrm{~d}$; in NH spring, subsidence occurs of air with D-enriched $\mathrm{H}_{2}$.

Both $\mathrm{N}_{2} \mathrm{O}$ and $\mathrm{CH}_{4}$ have sinks in the stratosphere. $\mathrm{CH}_{4}$ has no stratospheric sources; $\mathrm{N}_{2} \mathrm{O}$ may have a very small 


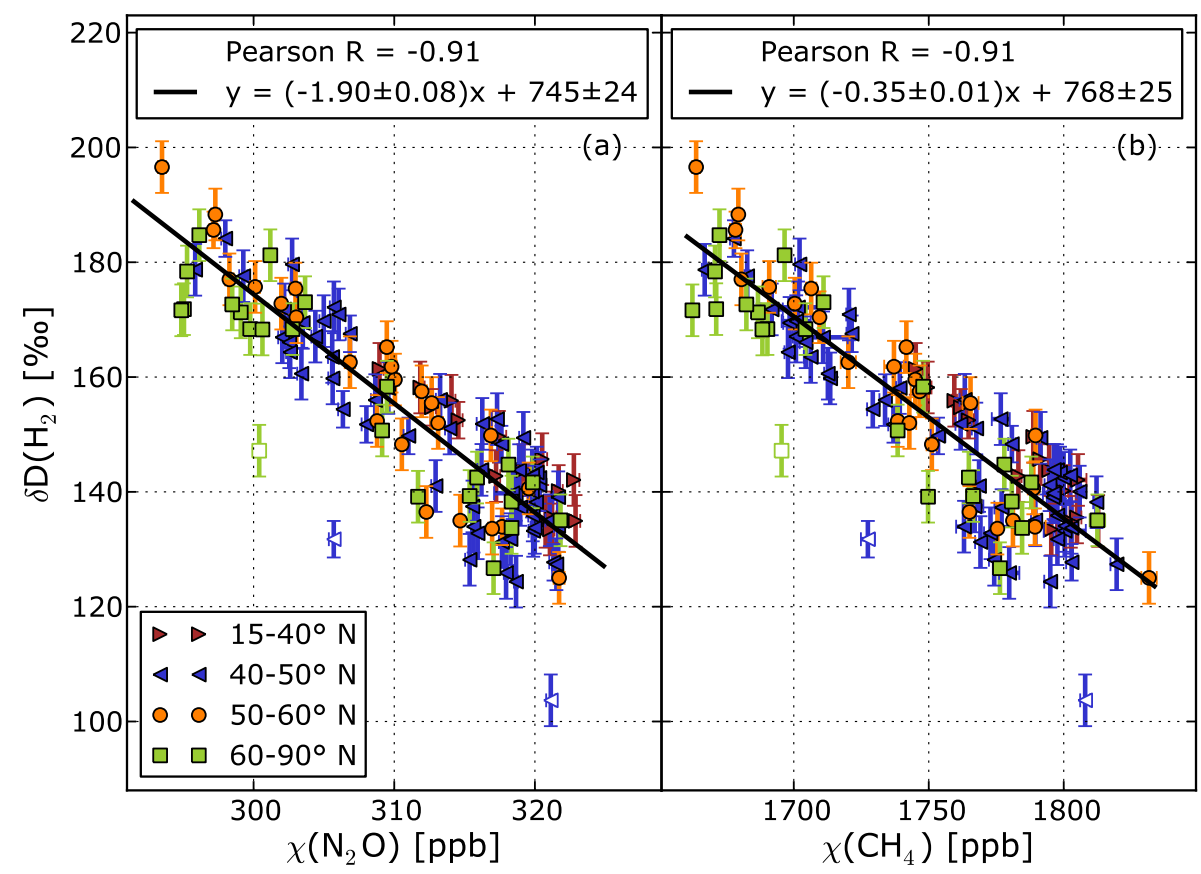

Fig. 5. $\delta \mathrm{D}$ plotted against $\chi\left(\mathrm{N}_{2} \mathrm{O}\right)$ (a) and $\chi\left(\mathrm{CH}_{4}\right)$ (b). Solid lines are W-Y fits (Cantrell, 2008). Different colors and markers indicate different sampling latitude bands. Open symbols denote outlying datapoints that were left out of the fitting procedure.

Table 2. Campaign description and correlations between $\delta \mathrm{D}$ or $\chi(\mathrm{HD})$ and methane from different publications. Methane mixing ratio data $\left(\chi\left(\mathrm{CH}_{4}\right)\right)$ from Rahn et al. (2003) and Röckmann et al. (2003) were multiplied by a factor of 1.0124 to convert them to the NOAA2004 scale. All fits were made with the Williamson-York algorithm described by Cantrell (2008). No error estimates for the individual measurements were taken into account for the literature values.

\begin{tabular}{|c|c|c|c|}
\hline Author & Campaign description & $\begin{array}{c}\delta \mathrm{D}\left(\mathrm{H}_{2}\right)[\% o]-\chi\left(\mathrm{CH}_{4}\right)[\mathrm{ppb}] \\
\text { correlation }\end{array}$ & $\begin{array}{c}\chi(\mathrm{HD})[\mathrm{ppb}]-\chi\left(\mathrm{CH}_{4}\right)[\mathrm{ppb}] \\
\text { correlation }\end{array}$ \\
\hline Rahn et al. (2003) & $\begin{array}{c}\text { Research aircraft } \\
11-21 \mathrm{~km} \\
65-80^{\circ} \mathrm{N} 11-63^{\circ} \mathrm{E} \\
\text { Jan-Mar } 2000\end{array}$ & $\begin{aligned} y= & (-0.29 \pm 0.02) x \\
& +627 \pm 21\end{aligned}$ & $\begin{array}{c}y=\left(-4.5 \cdot 10^{-5} \pm 3 \cdot 10^{-6}\right) x \\
+0.260 \pm 0.003\end{array}$ \\
\hline Röckmann et al. (2003) & $\begin{array}{c}\text { Balloon } \\
12-33 \mathrm{~km} \\
43.7^{\circ} \mathrm{N} 0.3^{\circ} \mathrm{W} \\
\text { Okt } 2002\end{array}$ & $\begin{array}{c}y=(-0.33 \pm 0.01) x \\
+724 \pm 7\end{array}$ & $\begin{array}{c}y=\left(-5.55 \cdot 10^{-5} \pm 8 \cdot 10^{-7}\right) x \\
+0.287 \pm 0.001\end{array}$ \\
\hline This work & $\begin{array}{l}\text { Commercial aircraft } \\
6.5-12.5 \mathrm{~km} \\
\approx \text { global } \\
2007-2010\end{array}$ & $\begin{aligned} y= & (-0.35 \pm 0.01) x \\
& +768 \pm 25\end{aligned}$ & $\begin{array}{c}y=\left(-6.1 \cdot 10^{-5} \pm 3 \cdot 10^{-6}\right) x \\
+0.307 \pm 0.004\end{array}$ \\
\hline
\end{tabular}

stratospheric source (Estupiñán et al., 2002). $\chi\left(\mathrm{CH}_{4}\right)$ and $\chi\left(\mathrm{N}_{2} \mathrm{O}\right)$ can therefore be used as an indicator of average degree of stratospheric processing that an air parcel has undergone. Plotting $\delta \mathrm{D}$ against $\chi\left(\mathrm{N}_{2} \mathrm{O}\right)$ and $\chi\left(\mathrm{CH}_{4}\right)$ (Fig. 5) shows very compact negative correlations for $\delta \mathrm{D}$ and these two greenhouse gases. There are no correlations with $\chi\left(\mathrm{H}_{2}\right)$ (not shown); no systematic spatial or temporal $\chi\left(\mathrm{H}_{2}\right)$ variation is observed in these data. So as the air ages, $\mathrm{N}_{2} \mathrm{O}$ and $\mathrm{CH}_{4}$ are destroyed, and $\mathrm{H}_{2}$ becomes progressively Denriched while its mixing ratio remains almost unchanged. Plumb (2007) showed that tight correlations exist between many long-lived stratospheric species. $\mathrm{H}_{2}, \mathrm{CH}_{4}$ and $\mathrm{N}_{2} \mathrm{O}$ all have chemical lifetimes that are longer than the transport times in the lower stratosphere, and as a result their distributions are determined by transport and/or mixing processes rather than by chemistry. This explains the tightness of the 


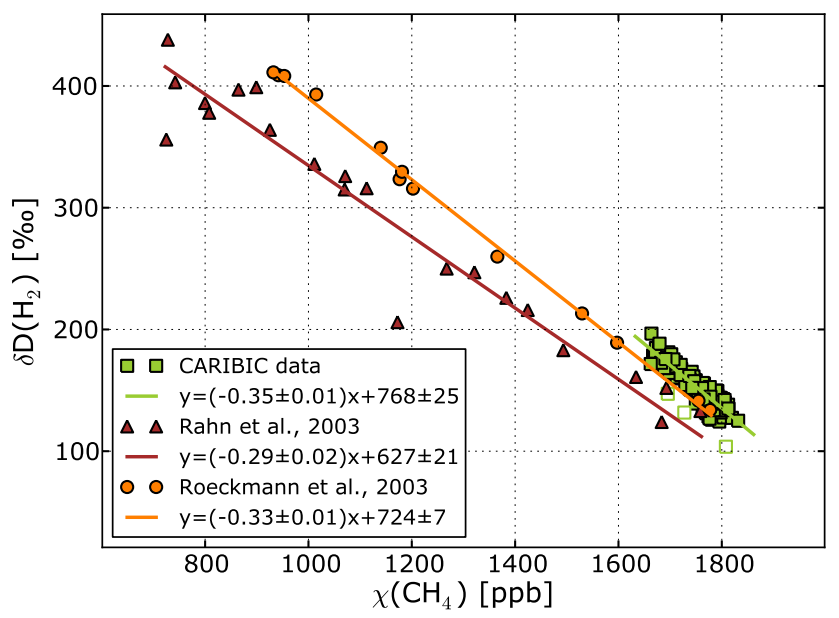

Fig. 6. $\delta \mathrm{D}$ plotted against $\chi\left(\mathrm{CH}_{4}\right)$, together with values from Rahn et al. (2003) and Röckmann et al. (2003) for comparison. Literature values were multiplied by a factor of 1.0124 to convert them to the NOAA2004 scale. Fits are made with the W-Y algorithm (Cantrell, 2008), without error estimates of the individual measurements for the literature values. Open symbols denote outlying datapoints that were left out of the fitting procedure.

observed correlations for both $\mathrm{CH}_{4}$, which has a chemical link with $\mathrm{H}_{2}$, and $\mathrm{N}_{2} \mathrm{O}$, which has none. We note that these correlations show that $\delta \mathrm{D}$ has potential for use as a tracer for stratospheric oxidation reactions of $\mathrm{H}$-containing species $\left(\mathrm{H}_{2}, \mathrm{CH}_{4}, \mathrm{H}_{2} \mathrm{O}, \mathrm{HCHO}\right)$.

Correlations between $\delta \mathrm{D}$ and mixing ratios of other stratospheric species were previously found by Rahn et al. (2003), Röckmann et al. (2003) and Rhee et al. (2006a). Comparisons of the CARIBIC data to the data from Rahn et al. (2003) and Röckmann et al. (2003) are shown in Table 2 and Fig. 6. Methane mixing ratio data from Rahn et al. (2003) and Röckmann et al. (2003) were multiplied by a factor of 1.0124 to convert them to the NOAA2004 scale. In the $\delta \mathrm{D}$ vs. $\chi\left(\mathrm{CH}_{4}\right)$ correlation plot (Fig. 6), a small offset occurs between the data from Rahn et al. (2003) and the new data presented here. From 2000 to 2009, the globally averaged $\chi\left(\mathrm{CH}_{4}\right)$ increased by $\approx 15 \mathrm{ppb}$ (Duglokencky et al., 2009). The offset between the CARIBIC correlation and the correlation from Rahn et al. (2003) seems considerably larger than that, and therefore it is likely that the largest part of the offset is caused by inter-laboratory differences. A possible but speculative explanation for part of the offset is that Rahn et al. (2003) sampled "older" stratospheric air than CARIBIC, as they sampled higher in the stratosphere with a stratospheric research aircraft. The air masses that they sampled may have been introduced into the stratosphere before 2000, when tropospheric methane levels were even lower, whereas CARIBIC probably samples air masses that were more recently imported into the stratosphere. The slope of the CARIBIC correlation is outside of the $2 \times$ SEM interval of the slope of the Rahn et al. (2003) correlation, and vice versa.

The agreement between the data from Röckmann et al. (2003) and the CARIBIC data is slightly better. At $130 \%$, close to the tropospheric average, the difference in $\chi\left(\mathrm{CH}_{4}\right)$ between the two correlation lines is $\approx 37 \mathrm{ppb}$, which is still more than twice the tropospheric $\mathrm{CH}_{4}$ increase. This may again be partly due to stratospheric age differences in the sampled air. The slopes, however, agree within one standard error.

That relatively good agreement between the slopes of the correlations of $\delta \mathrm{D}$ with $\chi\left(\mathrm{CH}_{4}\right)$ is found in samples of two very different platforms, at different altitudes and in different regions of the globe (see Table 2), indicates that these very likely hold globally. We expect, therefore, that the approach to approximate $\delta \mathrm{D}$ from an empirical correlation with another species (as, for example, in (Pieterse et al., 2011), where the relation from (McCarthy et al., 2004) is used) should give reasonable results as long as the parametrization that is used is appropriate.

When the average value of $\chi\left(\mathrm{H}_{2}\right)$ for the dataset $((559.2 \pm 1.5) \mathrm{ppb}$, without the outliers shown in Fig. 5) is used to calculate $\chi(\mathrm{HD})$ from the $\delta \mathrm{D}$ data and a straight-line (W-Y) fit is applied, the CARIBIC data yield:

$$
\begin{aligned}
& \chi(\mathrm{HD})[\mathrm{ppb}]=\left(-6.07 \cdot 10^{-5} \pm 2.5 \cdot 10^{-6}\right) \cdot \chi\left(\mathrm{CH}_{4}\right)[\mathrm{ppb}] \\
& +0.307 \pm 4.4 \cdot 10^{-3}
\end{aligned}
$$

The slope of the relation proposed by McCarthy et al. (2004) is (just) in the $1 \times \mathrm{SEM}$ interval of the slope of this correlation. We suggest that the relation found in the CARIBIC data discussed here may be the most appropriate choice for parameterizing the $\delta \mathrm{D}$ of the $\mathrm{H}_{2}$ that is mixed into the troposphere from the stratosphere, since all CARIBIC data are collected close to the region of interest for STE (i.e., just above the TP).

\subsection{Indian summer monsoon}

Six of the analyzed flights had Chennai (formerly Madras, India) as the destination airport. Of these flights, three took place in the summer monsoon season of 2008. Schuck et al. (2010) noted a marked increase in the mixing ratios of greenhouse gases over the Indian subcontinent in the summer monsoon period. This increase was most prominent in $\chi\left(\mathrm{CH}_{4}\right)$ and was attributed to increased microbial production of $\mathrm{CH}_{4}$ in the wet season and increased transport of boundary layer air to cruising altitude by convection.

These $\chi\left(\mathrm{CH}_{4}\right)$ data are plotted in Fig. 7a; the increase of methane levels in the wet season (blue tones) with respect to the dry season (red tones) can be seen clearly. The $\chi(\mathrm{CO})$, $\chi\left(\mathrm{H}_{2}\right)$ and $\delta \mathrm{D}$ data are plotted in Fig. $7 \mathrm{~b}, \mathrm{c}$ and d. $\chi(\mathrm{CO})$ shows an increase of up to $\approx 30 \mathrm{ppb}$ in the monsoon. An increase in $\chi\left(\mathrm{H}_{2}\right)$ is not apparent in these data, but a clear shift occurs in $\delta \mathrm{D}$. Monsoon samples seem at least $10 \%$ omore depleted than non-monsoon samples. Figure 8 a shows the $\delta \mathrm{D}$ 


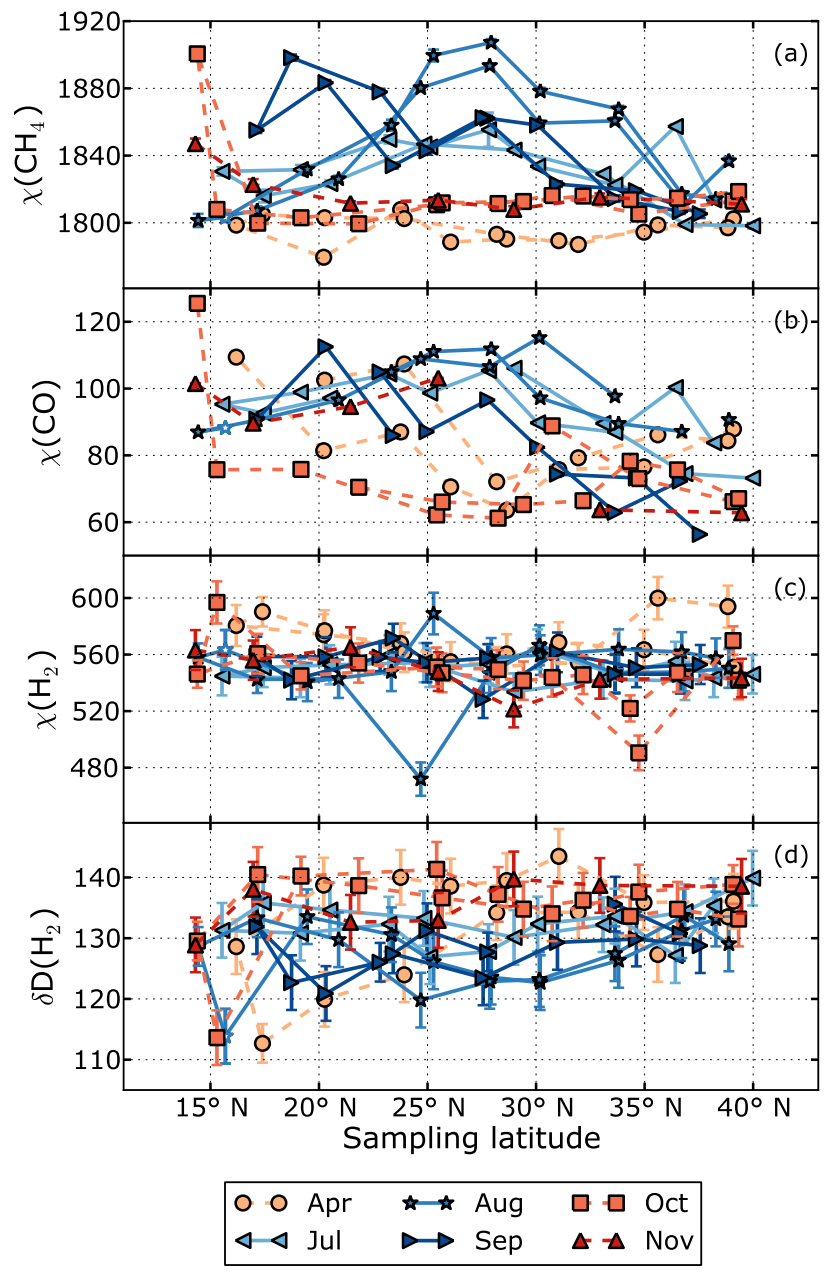

Fig. 7. $\chi\left(\mathrm{CH}_{4}\right)(\mathbf{a}), \chi(\mathrm{CO})(\mathbf{b}), \chi\left(\mathrm{H}_{2}\right)(\mathbf{c})$ and $\delta \mathrm{D}(\mathbf{d})$ for the samples taken on flights to Chennai south of $40^{\circ} \mathrm{N}$ in the monsoon season (blue tones) and outside the monsoon season of 2008 (red tones). The open symbol $\left(16^{\circ} \mathrm{N}\right)$ indicates a sample with a back trajectory originating outside of the monsoon system that was not taken into account in the fits.

plotted against $\chi\left(\mathrm{CH}_{4}\right)$ values for the three monsoon flights. A remarkably strong correlation is found between the two quantities. The correlation is not as strong as in the stratosphere, but clearly significant. The strong connection between the increase in $\chi\left(\mathrm{CH}_{4}\right)$ and the decrease in $\delta \mathrm{D}$ suggests that the processes that cause the $\mathrm{D}$-depletion coincide in time and space with the processes that cause the $\chi\left(\mathrm{CH}_{4}\right)$ increase.

Changes in $\delta \mathrm{D}$ at cruise altitude can be caused by changes in different variables, most importantly the strength and isotopic composition of $\mathrm{H}_{2}$ emissions at the ground and the efficiency of upward convective transport. Since there are no measurements of $\delta \mathrm{D}$ at the surface in India during this season, it is not possible to fully calculate how much each process contributes to the upper troposphere D-depletion. Nevertheless, we next explore the most likely scenarios.
Rhee et al. (2006b) argued that in biomass burning plumes from forest fires $\delta \mathrm{D}$ could be depleted while $\chi\left(\mathrm{H}_{2}\right)$ remains almost the same if a sink process such as soil uptake compensates for the mixing ratio effect of the source. Neither increased biomass burning nor increased soil uptake are likely in the Indian summer monsoon. The biomass burning maximum in India is in winter rather than summer (van der Werf et al., 2003), and the uptake of $\mathrm{H}_{2}$ is hindered in very wet soils, as the reactive $\mathrm{H}_{2}$-destroying sites in the soil pores are then covered by layers of water. Schmitt et al. (2009) reported that soil moisture is the major parameter controlling $\mathrm{H}_{2}$ uptake by soils, with a secondary role for temperature; it is therefore unlikely that an increased enzymatic activity due to increased temperatures in the monsoon could compensate for the decrease in diffusion of $\mathrm{H}_{2}$ to the reactive sites.

A second possible explanation is that $\mathrm{H}_{2}$ from fossil fuel combustion or household biomass burning emissions, that are not expected to vary much with season, is transported much more efficiently to cruise altitude due to the monsoon increase in convection. This would be in line with the observed increase in $\mathrm{CO}$, which is co-emitted with $\mathrm{H}_{2}$ in combustion processes. To assess this possibility we use the mass balance equation for mixing of polluted air with $\chi_{\mathrm{p}}\left(\mathrm{H}_{2}\right)$ and $\delta_{\mathrm{p}} \mathrm{D}$ with background air with $\chi_{\mathrm{bg}}\left(\mathrm{H}_{2}\right)$ and $\delta_{\mathrm{bg}} \mathrm{D}$, resulting in a mixture with $\chi_{\mathrm{p}+\mathrm{bg}}\left(\mathrm{H}_{2}\right)$ and $\delta_{\mathrm{p}+\mathrm{bg}} \mathrm{D}$ :

$$
\begin{aligned}
\chi_{\mathrm{p}+\mathrm{bg}}\left(\mathrm{H}_{2}\right) \delta_{\mathrm{p}+\mathrm{bg}} \mathrm{D} & =\left(\chi_{\mathrm{p}}\left(\mathrm{H}_{2}\right)+\chi_{\mathrm{bg}}\left(\mathrm{H}_{2}\right)\right) \delta_{\mathrm{p}+\mathrm{bg}} \mathrm{D} \\
& =\chi_{\mathrm{p}}\left(\mathrm{H}_{2}\right) \cdot \delta_{\mathrm{p}} \mathrm{D}+\chi_{\mathrm{bg}}\left(\mathrm{H}_{2}\right) \cdot \delta_{\mathrm{bg}} \mathrm{D}
\end{aligned}
$$

If the combustion emissions are assumed to have an average $\delta \mathrm{D}$ of $-230 \%$ (Table 1 ), and background values are assumed to be $556.4 \mathrm{ppb}$ and $+134.1 \%$ (the averages of the samples taken over India south of $40^{\circ} \mathrm{N}$ outside the monsoon season), it can be estimated from this mass balance equation that the observed $12.3 \%$ o depletion (the average of the five most depleted samples in the monsoon system) would in this case be accompanied by an $\approx 19.5 \mathrm{ppb}$ increase in $\chi\left(\mathrm{H}_{2}\right)$. We note that this value is of the order of magnitude that would be expected from the increase in $\chi(\mathrm{CO})$, since typical $\mathrm{H}_{2} / \mathrm{CO}$ emission ratios of combustion processes are between 0.3 and 0.5 (Popa et al., 2011; Haumann et al., 2012). This increase is, however, not observed in $\chi\left(\mathrm{H}_{2}\right)$. For the same reason as discussed above for forest fires, it is unlikely that soil uptake is compensating for the increase.

A third explanation is that extremely depleted $\mathrm{H}_{2}$ from microbial production is added to the mixture. Microbially produced $\mathrm{H}_{2}$ has a source signature of $(-741 \pm 13) \%$ o (Walter et al., 2011). With this, it can be calculated that if the observed depletion were caused exclusively by microbial production, it would be accompanied by a $\chi\left(\mathrm{H}_{2}\right)$ increase of $8.0 \mathrm{ppb}$, which is within the error range of our $\chi\left(\mathrm{H}_{2}\right)$ measurements. Also the correlation between $\delta \mathrm{D}$ and $\chi\left(\mathrm{CH}_{4}\right)$ is in agreement with production of $\mathrm{H}_{2}$ in the same wet soils, rice paddies or wetlands where $\mathrm{CH}_{4}$ production takes place.

If we assume that all of the D-depletion is caused by $\mathrm{H}_{2}$ from microbial production, we can use the mass balance 

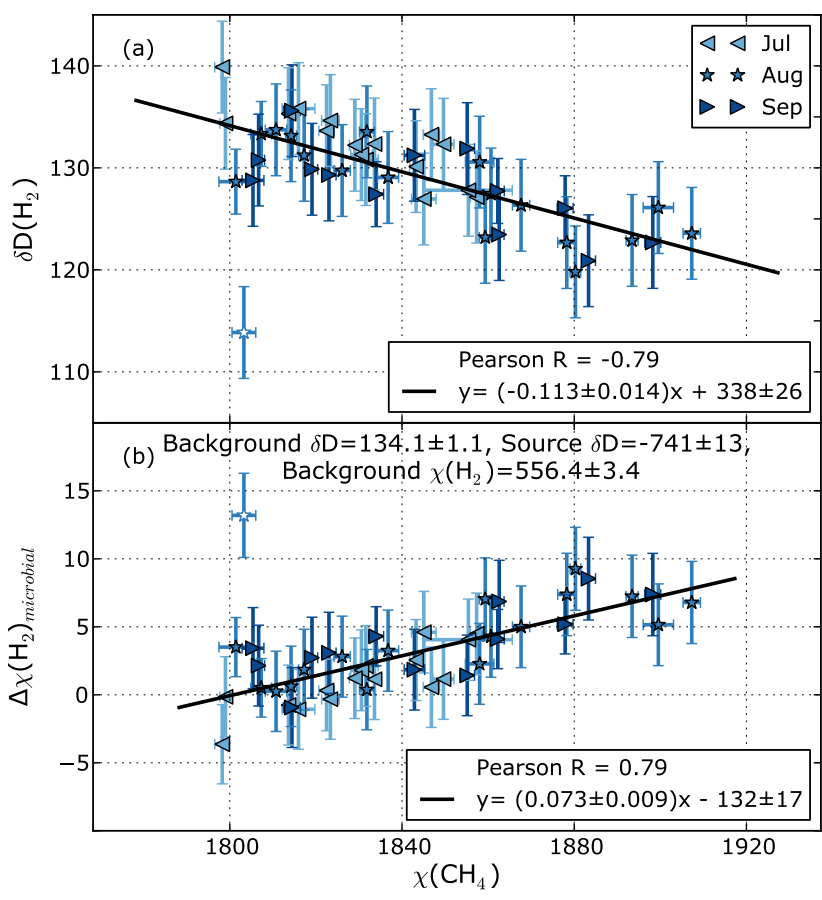

Fig. 8. (a): $\delta \mathrm{D}$ plotted against $\chi\left(\mathrm{CH}_{4}\right)$ for the samples taken on flights to Chennai south of $40^{\circ} \mathrm{N}$ in the summer monsoon season. (b): Estimated amount of $\mathrm{H}_{2}$ (as a $\chi\left(\mathrm{H}_{2}\right)$ increase) produced by monsoon-related microbial processes $\left(\Delta \chi\left(\mathrm{H}_{2}\right)_{\text {microbial }}\right)$ that would be required to explain the observed isotope depletions, plotted against $\chi\left(\mathrm{CH}_{4}\right)$. Calculations are done under the assumption that all D-depletion is caused by microbially produced $\mathrm{H}_{2}$ with a source signature of $\delta \mathrm{D}$ of $(-741 \pm 13) \%$ o (Walter et al., 2011). Solid lines indicate W-Y fits (Cantrell, 2008). The open symbol indicates a sample with a back trajectory originating outside of the monsoon system that was not taken into account in the fits.

equation (Eq. 3) to estimate the $\chi\left(\mathrm{H}_{2}\right)$ increase that would be necessary to cause it, $\Delta \chi\left(\mathrm{H}_{2}\right)_{\text {microbial }}$. Figure $8 \mathrm{~b}$ shows $\Delta \chi\left(\mathrm{H}_{2}\right)_{\text {microbial }}$ plotted against $\chi\left(\mathrm{CH}_{4}\right)$. A linear (W-Y) fit shows that in this case, the $\frac{\mathrm{H}_{2}}{\mathrm{CH}_{4}}$ emission ratio is $0.073 \pm 0.009$. According to the EDGAR database (V4.2, edgar.jrc.ec. europa.eu/ datasets_list.php?v=42), $8.50 \mathrm{Tg}$ of $\mathrm{CH}_{4}$ was produced in India in 2008 by rice cultivation and wastewater treatment. Our emission ratio estimate would then imply a concomitant production of $0.62 \mathrm{Tg} \mathrm{H} \mathrm{H}_{2}$. This is a large number compared to the $3 \mathrm{Tg}$ estimate for the global annual $\mathrm{H}_{2}$ production from $\mathrm{N}_{2}$ fixation that is often assumed in $\mathrm{H}_{2}$ budgets (Table 1), but the uncertainty estimate for this term is also large ( $3 \mathrm{Tg}$ ). It should also be noted that the estimates for this term are largely based on a study by Conrad and Seiler (1980) where $\mathrm{H}_{2}$ production measurements at two stations in Germany were scaled up to a global estimate. Little is known about the variation in $\mathrm{H}_{2}$ production between regions and ecosystems.

\section{Conclusions}

The large suite of measurements of $\chi\left(\mathrm{H}_{2}\right)$ and $\delta \mathrm{D}$ on samples taken onboard the CARIBIC aircraft demonstrates the usefulness of studying $\delta \mathrm{D}$ of $\mathrm{H}_{2}$ in the UTLS region. A few samples had unexpectedly high $\chi\left(\mathrm{H}_{2}\right)$ and low $\delta \mathrm{D}$ values. This tends to occur close to the departure or destination airports. We hypothesize that some of these events may be caused by the interception of exhaust plumes from other aircraft. The source signature of this pollution $(-420 \pm 31) \%$ is on the low end of what is expected for the combustion of fossil fuels. However, no relation is found with species that are usually expected in aircraft exhaust plumes. Measurement or sampling artifacts are unlikely since the measurements of these samples proceeded without other peculiarities.

More than 120 datapoints were obtained from the LMS, which greatly expands the existing $\delta \mathrm{D}$ dataset from this region. The $\delta \mathrm{D}$ data show a tight correlation with $\chi\left(\mathrm{N}_{2} \mathrm{O}\right)$ and $\chi\left(\mathrm{CH}_{4}\right)$. The relation with $\chi\left(\mathrm{CH}_{4}\right)$ follows the line $\delta \mathrm{D}[\% o]=(-0.35 \pm 0.01) \cdot \chi\left(\mathrm{CH}_{4}\right)[\mathrm{ppb}]+768 \pm 25$, which is close to the relation found by Röckmann et al. (2003), but somewhat steeper than the (Rahn et al., 2003) results. Since the correlations presented in this paper are compact and based on samples from many different locations around the world in the LMS, they are suitable for parameterizing STE in models.

A $\delta \mathrm{D}$ depletion by up to $12.3 \%$ was found in samples collected above India during the monsoon season, without an accompanying increase in $\chi\left(\mathrm{H}_{2}\right)$. Increased convective transport in the monsoon season transports D-depleted $\mathrm{H}_{2}$ from surface sources in the boundary layer more effectively to cruise altitude. If only combustion sources were responsible for the deuterium depletion, then either a concomitant increase in $\chi\left(\mathrm{H}_{2}\right)$ should be observed, or this increase would need to be compensated by increased soil uptake. Alternatively, increased microbial production of $\mathrm{H}_{2}$ in the monsoon could lead to the observed deuterium depletions, which would also explain the absence of a simultaneous (perceptible) increase in $\chi\left(\mathrm{H}_{2}\right)$. This requires further study, and we recommend investigations into possible $\mathrm{H}_{2}$ production in wet South Asian soils. Also, regular observations at a ground station in India would close a geographical gap in the ground station observations and could provide useful comparison material for the data presented here.

Continuation of the $\delta \mathrm{D}$ measurements on CARIBIC samples would provide the global coverage needed to validate global models, and could also resolve the seasonal and latitudinal variation of $\delta \mathrm{D}$ in the upper troposphere and the lowermost stratosphere better. 
Acknowledgements. We received financial support from the Dutch NWO-ACTS project 053.61.026. The CARIBIC project would not be possible without the support of Lufthansa.

We thank Thom Rahn for discussing scale issues with us, Armin Rauthe-Schöch for the calculation of mean trajectory parameters, and all the other participants in CARIBIC for many useful discussions.

A wealth of information on the CARIBIC project can be found on www.caribic-atmospheric.com.

Edited by: A. Engel

\section{References}

Batenburg, A. M., Walter, S., Pieterse, G., Levin, I., Schmidt, M., Jordan, A., Hammer, S., Yver, C., and Röckmann, T.: Temporal and spatial variability of the stable isotopic composition of atmospheric molecular hydrogen: observations at six EUROHYDROS stations, Atmos. Chem. Phys., 11, 6985-6999, doi:10.5194/acp11-6985-2011, 2011.

Batenburg, A. M., Popa, M. E., Vermeulen, A. T., van den Bulk, W. C. M., Jongejan, P. A. C., Fisher, R. E., Nisbet, E., , and Röckmann, T.: Hydrogen mixing ratio and stable isotopic composition observations at the Cabauw tall tower, to be submitted to J. Geophys. Res., 2012.

Bousquet, P., Yver, C., Pison, I., Li, Y. S., Fortems, A., Hauglustaine, D., Szopa, S., Rainer, P. J., Novelli, P., Langenfelds, R., Steele, P., Ramonet, M., Schmidt, M., Foster, P., Morfopoulos, C., and Ciais, P.: A three-dimensional synthesis inversion of the molecular hydrogen cycle: Sources and sinks budget and implications for the soil uptake, J. Geophys. Res, 116, D01302, doi:10.1029/2010JD014599, 2011.

Brenninkmeijer, C. A. M., Crutzen, P., Boumard, F., Dauer, T., Dix, B., Ebinghaus, R., Filippi, D., Fischer, H., Franke, H., Frieß, U., Heintzenberg, J., Helleis, F., Hermann, M., Kock, H. H., Koeppel, C., Lelieveld, J., Leuenberger, M., Martinsson, B. G., Miemczyk, S., Moret, H. P., Nguyen, H. N., Nyfeler, P., Oram, D., O’Sullivan, D., Penkett, S., Platt, U., Pupek, M., Ramonet, M., Randa, B., Reichelt, M., Rhee, T. S., Rohwer, J., Rosenfeld, K., Scharffe, D., Schlager, H., Schumann, U., Slemr, F., Sprung, D., Stock, P., Thaler, R., Valentino, F., van Velthoven, P., Waibel, A., Wandel, A., Waschitschek, K., Wiedensohler, A., Xueref-Remy, I., Zahn, A., Zech, U., and Ziereis, H.: Civil Aircraft for the regular investigation of the atmosphere based on an instrument container: The new CARIBIC system, Atmos. Chem. Phys., 7, 4953-4976, doi:10.5194/acp-7-4953-2007, 2007.

Cantrell, C. A.: Technical Note: Review of methods for linear leastsquares fitting of data and application to atmospheric chemistry problems, Atmos. Chem. Phys., 8, 5477-5487, doi:10.5194/acp8-5477-2008, 2008.

Conrad, R. and Seiler, W.: Contribution of Hydrogen Production by Biological Nitrogen Fixation to the Global Hydrogen Budget, J. Geophys. Res, 85, 5493-5498, doi:10.1029/JC085iC10p05493, 1980.

Duglokencky, E. J., Bruhwiler, L., White, J. W. C., Emmons, L. K., Novelli, P. C., Montzka, S. A., Masarie, K. A., Lang, P. M., Crotwell, A. M., Miller, J. B., and Gatti, L. V.: Observational constraints on recent increases in the atmospheric $\mathrm{CH}_{4}$ burden,
Geophys. Res. Lett., 36, L18803, doi:10.1029/2009GL039780, 2009.

Ehhalt, D. and Rohrer, F.: The tropospheric cycle of $\mathrm{H}_{2}$ : a critical review, Tellus B, 61, 500-535, doi:10.1111/j.16000889.2009.00416.x, 2009.

Estupiñán, E. G., Nocovich, J. M., Li, J., Cunnold, D. M., and Wine, P. H.: Investigation of $\mathrm{N}_{2} \mathrm{O}$ Production from 266 and $532 \mathrm{~nm}$ Laser Flash Photolysis of $\mathrm{O}_{3} / \mathrm{N}_{2} / \mathrm{O}_{2}$ Mixtures, J. Phys. Chem., 106, 5880-5890, doi:10.1021/jp014242c, 2002.

Feck, T., Grooß J.-U., and Riese, M.: Sensitivity of Arctic ozone loss to stratospheric $\mathrm{H}_{2} \mathrm{O}$, Geophys. Res. Lett., 35, 1-20, doi:10.1029/2007GL031334, 2008.

Feilberg, K. L., Johnson, M. S., Bacak, A., Röckmann, T., and Nielsen, C.: Relative photolysis rates of $\mathrm{HCHO}$ and HCDO measured at the European Photoreactor Facility, J. Phys. Chem. A, 111, 9034-9046, doi:10.1029/2007GL031334, 2007.

Gerst, S. and Quay, P.: The deuterium content of atmospheric molecular hydrogen: Method and initial measurements, J. Geophys. Res., 105, 26433-26445, doi:10.1029/2000JD900387, 2000.

Gerst, S. and Quay, P.: Deuterium component of the global molecular hydrogen cycle, J. Geophys. Res., 106, 5021-5031, doi:10.1029/2000JD900593, 2001.

Hauglustaine, D. A. and Ehhalt, D. H.: A three-imensional model of molecular hydrogen in the troposphere, J. Geophys. Res., 107, D174330, doi:10.1029/2001JD001156, 2002.

Haumann, A., Batenburg, A. M., Pieterse, G., Gerbig, C., and Röckmann, T.: Molecular hydrogen from biomass burning over the Amazonian tropical rainforest, to be submitted to Atmos. Environ, 2012.

Holton, J. R., Haynes, P. H., McIntyre, M. E., Douglas, A. R., Rood, R. B., and Pfister, L.: Stratosphere-troposphere exchange, Rev. Geophys., 33, 403-439, doi:10.1029/95RG02097, 1995.

Jordan, A. and Steinberg, B.: Calibration of atmospheric hydrogen measurements, Atmos. Meas. Tech., 4, 509-521, doi:10.5194/amt-4-509-2011, 2011.

McCarthy, M. C., Boering, K. A., Rahn, T., Eiler, J., Rice, A., Tyler, S. C., Atlas, E., and Johnson, D. G.: The hydrogen isotopic composition of water vapor entering the stratosphere inferred from high precision measurements of $\delta \mathrm{D}-\mathrm{CH}_{4}$ and $\delta \mathrm{D}-\mathrm{H}_{2}$, J. Geophys. Res., 109, D07304, doi:10.1029/2003JD004003, 2004.

Nilsson, E. J. K., Johnson, M. S., Taketani, F., Matsumi, Y., Hurley, M. D., and Wallington, T. J.: Atmospheric deuterium fractionation: $\mathrm{HCHO}$ and $\mathrm{HCDO}$ yields in the $\mathrm{CH}_{2} \mathrm{DO}+\mathrm{O}_{2}$ reaction, Atmos. Chem. Phys., 7, 5873-5881, doi:10.5194/acp-7-5873-2007, 2007.

Nilsson, E. J. K., Andersen, V. F., Skov, H., and Johnson, M. S.: Pressure dependence of the deuterium isotope effect in the photolysis of formaldehyde by ultraviolet light, Atmos. Chem. Phys., 10, 3455-3462, doi:10.5194/acp-10-3455-2010, 2010.

Novelli, P. C., Lang, P. M., Masarie, K. A., Hurst, D. F., Myers, R., and Elkins, J. W.: Molecular Hydrogen in the troposphere: Global distribution and budget, J. Geophys. Res., 104, 3042730444, doi:10.1029/1999JD900788, 1999.

Pieterse, G., Krol, M. C., and Röckmann, T.: A consistent molecular hydrogen isotope chemistry scheme based on an independent bond approximation, Atmos. Chem. Phys., 9, 8503-8529, doi:10.5194/acp-9-8503-2009, 2009. 
Pieterse, G., Krol, M. C., Batenburg, A. M., Steele, L. P., Kummel, P. B., Langenfelds, R. L., and Röckmann, T.: Global modelling of $\mathrm{H}_{2}$ mixing ratios and isotopic compositions with the TM5 model, Atmos. Chem. Phys., 11, 7001-7026, doi:10.5194/acp-11-70012011, 2011.

Pieterse, G., Krol, M. C., Batenburg, A. M., Brenninkmeijer, C. A. M., Popa, M. E., O’Doherty, S., Grant, A., Steele, L. P., Krummel, P. B., Langenfelds, R. L., Wang, H. J., Vermeulen, A. T., Schmidt, M., Jordan, A., Engel, A., Fisher, R. E., Lowry, D., Nisbet, E. G., Reimann, S., Vollmer, M. K., Steinbacher, M., Levin, I., Hammer, S., Sturges, W. T., and Röckmann, T.: Modelling the global and regional scale variability in atmospheric $\mathrm{H}_{2}$ with the two-way nested TM5 model, J. Geophys. Res., submitted, 2012.

Plumb, R.: Tracer interrelationships in the stratosphere, Rev. Geophys., 45, RG4005, doi:10.1029/2005RG000179, 2007.

Popa, M. E., Vermeulen, A. T., van den Bulk, W. C. M., Jongejan, P. A. C., Batenburg, A. M., Zahorowski, W., and Röckmann, T.: $\mathrm{H}_{2}$ vertical profiles in the continental boundary layer: measurements at the Cabauw tall tower in the Netherlands, Atmos. Chem. Phys., 11, 6425-6443, doi:10.5194/acp-11-6425-2011, 2011.

Price, H., Jaeglé, L., Rice, A., Quay, P., and Novelli, P. C.: Global budget of molecular hydrogen and its deuterium content: Constraints from ground station, cruise and aircraft observations, J. Geophys. Res., 112, D22108, doi:10.1029/2006JD008152, 2007.

Rahn, T., Eiler, J. M., Kitchen, N., Fessenden, J. E., and Randerson, J. T.: Concentration and $\delta \mathrm{D}$ of molecular hydrogen in boreal forests: Ecosystem-scale systematics of atmospheric $\mathrm{H}_{2}$, Geophys. Res. Lett, 29, 1888, doi:10.1029/2002GL015118, 2002a.

Rahn, T., Kitchen, N., and Eiler, J.: D/H ratios of atmospheric $\mathrm{H}_{2}$ in urban air: Results using new methods for analysis of nanomolar $\mathrm{H}_{2}$ samples, Geochim. and Cosmochim. Ac., 66, 24752481, doi:10.1016/S0016-7037(02)00858-X, 2002b.

Rahn, T., Eiler, J. M., Boering, K. A., Wennberg, P. O., McCarthy, M. C., Tyler, S., Schauffler, S., Donnelly, S., and Atlas, E.: Extreme deuterium enrichment in stratospheric hydrogen and the global atmospheric budget of $\mathrm{H}_{2}$, Nature, 424, 918-921, doi:10.1038/nature01917, 2003.

Rhee, T. S., Mak, J., Röckmann, T., and Brenninkmeijer, C. A. M.: Continuous-flow isotope analysis of the deuterium/hydrogen ratio in atmospheric hydrogen, Rapid Commun. Mass Spectrom., 18, 299-306, doi:10.1002/rcm.1309, 2004.

Rhee, T. S., Brenninkmeijer, C. A. M., Braß, M., and Brühl, C.: Isotopic composition of $\mathrm{H}_{2}$ from $\mathrm{CH}_{4}$ oxidation in the stratosphere and the troposphere, J. Geophys. Res., 111, D23303, doi:10.1029/2005JD006760, 2006a.

Rhee, T. S., Brenninkmeijer, C. A. M., and Röckmann, T.: The overwhelming role of soils in the global atmospheric hydrogen cycle, Atmos. Chem. Phys., 6, 1611-1625, doi:10.5194/acp-61611-2006, 2006b.

Rhee, T. S., Brenninkmeijer, C. A. M., and Röckmann, T.: Hydrogen isotope fractionation in the photolysis of formaldehyde, Atmos. Chem. Phys., 8, 1353-1366, doi:10.5194/acp-8-1353-2008, 2008.

Rice, A., Quay, P., Stutsman, J., Gammon, R., Price, H., and Jaeglé, L.: Meridional distribution of molecular hydrogen and its deuterium content in the atmosphere, J. Geophys. Res., 115, D12306, doi:10.1029/2009JD012529, 2010.

Rice, A., Dayalu, A., Quay, P., and Gammon, R.: Isotopic fractionation during soil uptake of atmospheric hydrogen, Biogeo- sciences, 8, 763-769, doi:10.5194/bg-8-763-2011, 2011.

Röckmann, T., Rhee, T. S., and Engel, A.: Heavy hydrogen in the stratosphere, Atmos. Chem. Phys., 3, 2015-2023, doi:10.5194/acp-3-2015-2003, 2003.

Röckmann, T., Álvarez, C. X., Walter, S., van der Veen, C., , Wollny, A. G., Gunthe, S. S., Helas, G., Pöschl, U., Keppler, F., Greule, M., and Brand, W. A.: Isotopic composition of $\mathrm{H}_{2}$ from wood burning: Dependency on combustion efficiency, moisture content, and $\delta \mathrm{D}$ of local precipitation, J. Geophys. Res., 115, D17308, doi:10.1029/2009JD013188, 2010a.

Röckmann, T., Walter, S., Bohn, B., Wegener, R., Spahn, H., Brauers, T., Tillmann, R., Schlosser, E., Koppmann, R., and Rohrer, F.: Isotope effect in the formation of $\mathrm{H}_{2}$ from $\mathrm{H}_{2} \mathrm{CO}$ studied at the atmospheric simulation chamber SAPHIR, Atmos. Chem. Phys., 10, 5343-5357, doi:10.5194/acp-10-53432010, 2010b.

Sander, S. P., Finlayson-Pitts, B. J., Friedl, R. R., Golden, D. M., Huie, R. E., Keller-Rudek, H., Kolb, C. E., Kurylo, M. J., Molina, M. J., Moortgat, G. K., Orkin, V. L., and Wine, P. H.: Chemical kinetics and photochemical data for use in atmospheric studies, in: Evaluation number 15, Technical Report, Jet Propulsion Laboratory, Pasadena, USA, JPL Publication 06-2, 1275, 2006.

Sanderson, M. G., Collins, W. J., Derwent, R. G., and Johnson, C. E.: Simulation of global hydrogen levels using a Lagrangian three-dimensional model, J. Atmos. Chem., 46, 15-28, doi:10.1023/a:1024824223232, 2003.

Scharffe, D., Slemr, F., Brenninkmeijer, C. A. M., and Zahn, A.: Carbon monoxide measurements onboard the CARIBIC passenger aircraft using UV resonance flurescence, Atmos. Meas. Tech. Discuss., 5, 2681-2701, doi:10.5194/amtd-5-2681-2012, 2012.

Schmitt, S., Hanselmann, A., Wollschläger, U., Hammer, S., and Levin, I.: Investigation of parameters controlling the soil sink of atmospheric molecular hydrogen, Tellus, 61B, 416-423, doi:10.1111/j.1600-0889.2008.00402.x, 2009.

Schuck, T. J., Brenninkmeijer, C. A. M., Slemr, F., Xueref-Remy, I., and Zahn, A.: Greenhouse gas analysis of air samples collected onboard the CARIBIC passenger aircraft, Atmos. Meas. Tech., 2, 449-464, doi:10.5194/amt-2-449-2009, 2009.

Schuck, T. J., Brenninkmeijer, C. A. M., Baker, A. K., Slemr, F., van Velthoven, P. F. J., and Zahn, A.: Greenhouse gas relationships in the Indian summer monsoon plume measured by the CARIBIC passenger aircraft, Atmos. Chem. Phys., 10, 39653984, doi:10.5194/acp-10-3965-2010, 2010.

Schultz, M. G., Diehl, T., Brasseur, G. P., and Zittel, W.: Air pollution and climate-forcing impacts of a global hydrogen economy, Science, 302, 624-627, doi:10.1126/science.1085169, 2003.

Sprung, D. and Zahn, A.: Acetone in the upper troposphere/lowermost stratosphere measured by the CARIBIC passenger aircraft: Distribution, seasonal cycle, and variability, J. Geophys. Res., 115, D16301, doi:10.1029/2009JD012099, 2010.

Talukdar, R. K., Gierczak, T., Goldfarb, L., Rudich, Y., Rao, B. S. M., and Ravishankara, A. R.: Kinetics of Hydroxyl Radical Reactions with Isotopically Labeled Hydrogen, J. Phys. Chem., 100, 3037-3047, doi:10.1021/jp9518724, 1996.

Tromp, T. K., Shia, R.-L., Allen, M., Eiler, J. M., and Yung, Y. L.: Potential environmental impact of a hydrogen economy on the stratosphere, Science, 300, 1740-1742, doi:10.1126/science.1085169, 2003. 
van der Werf, G. R., Randerson, J. T., Collatz, G. J., and Giglio, L.: Carbon emissions from fires in tropical and subtropical ecosytems, Global Change Biol., 9, 547-562, doi:10.1046/j.1365-2486.2003.00604.x, 2003.

van Velthoven, P. F. J.: Meteorological analysis of CARIBIC by KNMI, http://www.knmi.nl/samenw/campaign_support/ CARIBIC/\#LH, last access December 2nd, 2011, 2009.

Vollmer, M. K., Walter, S., Bond, S. W., Soltic, P., and Röckmann, T.: Molecular hydrogen $\left(\mathrm{H}_{2}\right)$ emissions and their isotopic signatures (H/D) from a motor vehicle: implications on atmospheric $\mathrm{H}_{2}$, Atmos. Chem. Phys., 10, 5707-5718, doi:10.5194/acp-105707-2010, 2010.

Walter, S., Laukenmann, S., Stams, A. J. M., Vollmer, M. K., Gleixner, G., and Röckmann, T.: The stable isotopic signature of biologically produced molecular hydrogen $\left(\mathrm{H}_{2}\right)$, Biogeosci. Discuss., 8, 12521-12541, doi:10.5194/bgd-8-12521-2011, 2011.

Warwick, N. J., Bekki, S., Nisbet, E. G., and Pyle, J. A.: Impact of a hydrogen economy on the stratosphere and troposphere studied in a 2-D model, Geophys. Res. Lett, 31, 2-5, doi:10.1029/2003GL019224, 2004.

Xiao, X., Prinn, R. G., Simmonds, P. G., Steele, L. P., Novelli, P. C., Huang, J., Langenfelds, R. L., O'Doherty, S., Krummel, P. B., Fraser, P. J., Porter, L. W., Weiss, R. F., Salameh, P., and Wange, R. H. J.: Optimal estimation of the soil uptake rate of molecular hydrogen from the Advanced Global Atmospheric Gases Experiment and other measurements, J. Geophys. Res., 112, D07303, doi:10.1029/2006JD007241, 2007.
Yashiro, H., Sudo, K., Yonemura, S., and Takigawa, M.: The impact of soil uptake on the global distribution of molecular hydrogen:chemical transport model simulation, Atmos. Chem. Phys., 11, 6701-6719, doi:10.5194/acp-11-6701-2011, 2011.

Yver, C., Pison, I., Fortems-Cheiney, A., Schmidt, M., Bousquet, P., Ramonet, M., Jordan, A., Søvde, A., Engel, A., Fisher, R., et al.: A new estimation of the recent tropospheric molecular hydrogen budget using atmospheric observations and variational inversion, Atmos. Chem. Phys, 11, 3375-3392, doi:10.5194/acp/11-33752011, 2011.

Ziereis, H., Schlager, H., Schulte, P., van Velthoven, P., and Slemr, F.: Distributions of $\mathrm{NO}, \mathrm{NO}_{x}$, and $\mathrm{NO}_{y}$ in the upper troposphere and lower stratosphere between $28^{\circ}$ and $61^{\circ} \mathrm{N}$ during POLINAT 2, J. Geophys. Res., 105, 3653-3664, doi:10.1029/1999JD900870, 2000. 